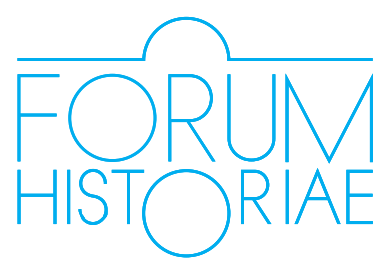

\title{
Země nikoho 1938. Deportace za hranice občanství
}

\author{
Michal Frankl
}

\begin{abstract}
:
FRANKL, Michal: No Man's Land in 1938. Deportation beyond the Bounds of Citizenship.

In November 1938, following the First Vienna Award and the loss of Southern Slovakia, the leadership of the autonomous Slovakia triggered the deportations of thousands of Jews into a region that was to be taken over by Hungary. Many of them were forced into a strip of land along the new demarcation line, between the Czechoslovak and Hungarian posts, into no man's land. The article collates the scarce evidence scattered within Slovak and international archives, in published and unpublished testimonies and memoires in order to understand the nature of this no man's land of refugees which was multiplied by the shifting borders of East-Central Europe in 1938.

While the existing historiography and editions of documents has provided ample information about the decision-making process behind the 1938 deportations and the course they took, the refugees no man's land close to Miloslavov / Mischdorf / Miserd, among other - even less well known - cases, has not been explored from within, as a social space characterized by the withdrawal of the state and a lack of social structures. In an exploration of the terminology used to label these spaces and capture the refugee experience, the article analyzes the no man's land as a space of exclusion and abandonment, a form of a territorialized statelessness. In the absence of the state, Jewish aid organizations provided food and material help and attempted to organize emigration - thus providing an improvised and imperfect replacement of citizenship. This no man's land was an unstable and shifting space: the article explores its transitions during the transfer of authority to Southern Slovakia as well as the later spread of this no man's land within Slovak territory - as extraterritorial spaces where unwanted Jews were kept in limbo, for instance the camps on the outskirts of Bratislava, at Červený Most / Rote Brücke and Patrónka. Keywords: No man's land, Refugees, Deportations 1938, Citizenship, Jews, Miloslavov, Vel'ký Kýr DOI: https://doi.org/10.31577/forhist.2019.13.1.7
\end{abstract}

\begin{abstract}
Když jsme do tohoto území pronikli dvěstě nebo třista kroků, vynořily se před ر námi nevyspale vypadající postavy, kterých stále přibývalo. [...] Několik set metrů před námi jsme viděli slovenské pohraniční hlídky, za námi se utvořil řetěz mad’arských pohraničníků, kteří nám bránili v návratu. Mezi tím se nacházel široký pruh demarkační linie, jak zní technický výraz pro zónu vytvořenou posunem mezinárodní hranice. Byli jsme nič́ lidé [Niemande, M. F.] v »zemi nikoho«." ${ }^{11}$
\end{abstract}

Těmito slovy líčil Egon Schwarz, jeden z tisíců Židů deportovaných z území autonomního Slovenska po první Vídeňské arbitráži, své první dojmy ze země nikoho

\footnotetext{
* Tato studie vznikla v rámci projektu „Občané země nikoho. Židovští uprchlíci a eroze občanství ve středovýchodní Evropě, 1935-1939“ podpořeného Grantovou agenturou ČR, č. 18-16793S. Výzkum byl dále umožněn stipendiem Margit Meissner v Jack, Joseph and Morton Mandel Center for Advanced Holocaust Studies v US Holocaust Memorial Museum, Sorrell and Lorraine Chesin/JDC Archives Fellowship a stipendiem ve Vienna Wiesenthal Institute for Holocaust Studies. Za odkazy na prameny a literaturu děkuji Michale Lônčíkové, Martinu Šmokovi a Évě Kovács.
}

1 SCHWARZ, Egon. Unfreiwillige Wanderjahre. Auf der Flucht vor Hitler durch drei Kontinente. München : Beck, 2009, s. 69. 
mezi obcemi Miloslavov a Štvrtok na Ostrove. Schwarz, tehdy šestnáctiletý, spolu s rodiči v létě 1938 ilegálně utekl z Vídně do Bratislavy, kde po několik měsíců žil u rodiny jeho matky a kde příležitostně na černo pracoval - roznášel mléko nebo vyučoval jazyky. Ve svých vzpomínkách líčí, jak se po vyhlášení výsledků první Vídeňské arbitráže (2. listopadu 1938) pod vedením energického strýce ukrývali před raziemi, při nichž byli zatýkáni a deportováni cizí Židé. Protože prohlídky bytů se zpravidla konaly v noci, celá rodina v nočních hodinách opatrně procházela ulicemi Bratislavy a vyhýbala se Hlinkově gardě. Počáteční štěstí vypršelo, když je překvapila hlídka, jež nečekaně vyšla z domu přímo před nimi. Do 5. listopadu takto vyvezla bratislavská policie 260 „cizinců“, z nichž většina měli být Židé. Nejprve byli autobusy dopraveni na policejní ředitelství, odkud byli v nočních hodinách nákladními vozy odvezeni na odstupované území. ${ }^{2}$ Egon se tak i s rodiči octl mezi bratislavskými Židy deportovanými za demarkační čáru. ${ }^{3}$

Téma deportací slovenských Židů v listopadu 1938 není ve slovenské historiografii nikterak nové. V mnoha ohledech vyčerpávající dokumentaci shromáždil zejména Eduard Nižňanský ${ }^{4}$ a řadu detailů lze nalézt ve studiích věnovaných dějinám jednotlivých židovských obcí nebo regionů v době holokaustu. ${ }^{5}$ Analýza deportací je z pochopitelných důvodů soustředěna kolem kontextů a témat období autonomie, omezování politických svobod, přechodu k vládě Hlinkovej slovenskej l'udovej strany (HSLS) a expanze násilí ze strany Hlinkovy gardy. ${ }^{6} \mathrm{~V}$ těchto významných pracích je patrné jejich zaměření na Slovensko a diskusi o podílu představitelů slovenského státu na holokaustu, stejně jako obecnější zaměření na státní aktéry a jejich snahy o zastavení a kontrolu uprchlíků. Historici se zabývali rolí antisemitismu a protižidovské politiky v rámci vymezování se vůči Praze a snahy o dosažení nezávislosti Slovenska. Usilovali o rekonstrukci rozhodovacího procesu a zodpovědnosti jednotlivých činitelů, at' již to byl Josef Tiso, nebo Adolf Eichmann, a dokumentovali organizaci a průběh deportací. V tomto smyslu je také dominantní historiografický přístup tematicky a metodologicky bližší studiím o deportacích v roce 1942.

V mezinárodní historiografii o holokaustu zůstávají slovenské deportace z roku 1938 a země nikoho jen poznámkou pod čarou. ${ }^{7}$ Výjimkou je článek historika

2 Slovenský národný archív (SNA), fond (f.) Krajinský úrad v Bratislave (KÚ BA), karton (k.) 309, č. j. 70581/38, Zpráva policejního ředitele, 5. listopadu 1938.

3 SCHWARZ 2009, s. 64-66.

4 NIŽŇANSKÝ, Eduard (ed.) Holokaust na Slovensku. Obdobie autonómie (6. 10. 1938 - 14. 3. 1939). Bratislava : Nadácia Milana Šimečku - Židovská náboženská obec, Bratislava, 2001; NIŽŇANSKÝ, Eduard. Židovská komunita na Slovensku medzi československou parlamentnou demokraciou a slovenským štátom v stredoeurópskom kontexte. Prešov : Universum, 1999. Viz též řadu dalších studií Eduarda Nižňanského.

5 HLAVINKA, Ján. Židovská komunita v okrese Medzilaborce v rokoch 1938 - 1945. Bratislava : Ústav pamäti národa, 2007; PAULOVIČOVÁ, Nina. Židovská komunita v dejinách mesta Hlohovec, 1938 - 1945. Príbeh, ktorý prešiel tmou. Hlohovec : Ex Libris Ad Personam (ELAP), 2009; FIAMOVÁ, Martina. Deportácie Židov v novembri 1938 v Zlatých Moravciach. In SLNEKOVÁ, Veronika - ZUBÁCKA, Ida (eds.) Criepky z dejín Slovenska. Nitra : Univerzita Konštantína Filozofa, 2011; KÖNÖZSYOVÁ, Lucia. Deportácie Židov z Nitry za autonómie Slovenska 4. - 5. 11. 1938 v dokumentoch. In Studia Historica Nitriensia, 2000, roč. 8, s. 241-298. 6 SCHVARC, Michal - HOLÁK, Martin - SCHRIFFL, David (eds.) Tretia ríša a vznik Slovenského štátu: dokumenty / Das "Dritte Reich" und die Entstehung des Slowakischen Staates: Dokumente. Bratislava : Ústav pamäti národa, 2008; SOKOLOVIČ, Peter. Hlinkova garda 1938 - 1945. Bratislava : Ústav pamäti národa, 2009, s. 111-117.

7 Viz například ZAHRA, Tara. The Great Departure. Mass Migration from Eastern Europe and the Making of the Free World. New York : W. W. Norton \& Company, 2016, s. 148-149. 
Jamese Warda, který zdůraznil zvláštní význam mad’arsko-slovenského konfliktu a první Vídeňské arbitráže jako formativní zkušenosti pro další formy a průběh holokaustu na Slovensku. ${ }^{8}$ Raz Segal si v dějinách holokaustu na Podkarpatské Rusi povšiml dosud téměř neznámého vypovídání Židů a země nikoho v tomto regionu, jež interpretuje jako součást procesů mnohovrstevnatého násilí v pohraničním regionu a dezintegrace multietnické společnosti, v níž dříve Židé a Rusíni žili ve shodě. ${ }^{9}$

I když víme hodně o deportacích samotných, zkušenost ze země nikoho, jako ta Egona Schwarze, $\mathrm{k}$ jehož svědectví se v této studii budu vracet, v dosavadních studiích zaniká. $V$ téhle studii se podívám na tytéž události z jiné perspektivy: vedle ohledávání země nikoho zvnějšku se pokusím nahlédnout dovnitř a tázat se, jak takové území a v něm improvizované společenství vypovězených fungovalo a jakými pravidly se ř́́dilo. Kromě dokumentů ze slovenských archivů, z nichž již byla řada zveřejněna a interpretována Eduardem Nižňanským a dalšími, využívám také nové materiály a svědectví ze zahraničních archivů. Zemi nikoho zároveň rekontextualizuji jako součást transnacionálních procesů charakteristických pro dramatickou radikalizaci protižidovské politiky v roce 1938. Transnacionální perspektiva $\mathrm{v}$ tomto př́padě umožňuje sledovat procesy vylučování např́č národními státy, $\mathrm{v}$ př́mé, komplexní a vícesměrné interakci mezi jejich úředníky, novináři, policisty či vojáky. Hranici je třeba vnímat nejen jako dělítko, ale také jako zónu setkávání a zprostředkování, jako hlavní rozhraní pro přijetí či vyloučení, kde státy signalizovaly a vyjednávaly své představy o národní př́íslušnosti a charakteru občanství, o vztahu mezi státem, teritoriem a populací.

\section{„Rychlé řešení židovského problému“}

Kolem poledne 4. listopadu 1938, necelé dva dny po vídeňském rozhodnutí, jímž bylo jižní Slovensko přriřčeno Mad’arsku, obdržely okresní úřady urgentní rozkaz Josefa Tisa, předsedy slovenské autonomní vlády a ministra vnitra. Instrukce, které pouze telefonicky sdělili úředníci Policejního ředitelství v Bratislavě, neměly za cíl nic menšího než „rýchl[e] vyriešeni[e] židovského problému na Slovensku“, ${ }^{10}$ přičemž zprávy o realizaci opatření měly být podávány dosud neexistující Centrále pre riešenie židovského problému na Slovensku při policejním ředitelství. Deportace slovenských Židů byly - at' již v jakémkoli poměru - důsledkem kombinace antisemitské interpretace první Vídeňské arbitráže a vlivu vypovídání vyhánění Židů z nacistického Německa.

Deportace do odstoupeného území nebyly zcela výjimečné - po vídeňském rozhodnutí vydávaly (česko-)slovenské úřady řadu nařízení kontrolujících pohyb obyvatel a majetku přes nově vznikající hranici podle etnických kritérií. Například

8 WARD, James Mace. The 1938 First Vienna Award and the Holocaust in Slovakia. In Holocaust and Genocide Studies, 2015, roč. 29, č. 1, s. 76-108.

9 SEGAL, Raz. Genocide in the Carpathians: War, Social Breakdown, and Mass Violence, 1914 - 1945. Stanford, California : Stanford University Press, 2016, s. 57.

10 United States Holocaust Memorial Museum (USHMM), f. RG-57.007M, Selected records from the State Regional Archive in Modra, Slovak Republic, reel 1, Záznam fonogramu, Okresní úřad Modra, 4. listopadu 1938, 12 hod.; NIŽŇANSKÝ 2001, dokument č. 110, s. 228-230. 
již 2. listopadu nařídil Krajinský úrad v Bratislave, aby Židé z odstoupených okresů zůstali ve svých bydlištích (na rozdíl od slovenských "kolonistů“ a československých státních zaměstnanců, jejichž evakuace se očekávala). Zároveň měly okresní úřady na jižní Slovensko poslat „potulné cikány“, kteří „sú väčšinou bez domovského práva a štátneho občianstva". ${ }^{11}$ Tato opatření byla velmi podobná přístupu československých úřadů k pomnichovským uprchlíkům z českého pohraničí. Nařízení o deportacích Židů se však svými proporcemi a razancí od takových kroků lišilo.

Časový rámec slovenských deportací a aktivit Adolfa Eichmanna přesahuje kontext první Vídeňské arbitráže a odstupování jižního Slovenska. Spadaly totiž do několika málo dnů mezi nacistickými deportacemi Židů s polskou státní příslušností a křištálovou nocí, nacisty zorganizovaným pogromem. Vypovězení a systematické deportace až 20 tisíc polských Židů na konci ř́jna 1938 byly významným milníkem v postupném procesu radikalizace a „očištování“ od Židů, od násilného vyhánění k organizovaným masovým transportům. Bratislavskou intervenci Adolfa Eichmanna, at' již přesně probíhala jakkoli, je proto možné chápat jako transfer zkušenosti s německými deportacemi, jež se uskutečnily jen o několik dní dříve. ${ }^{12}$

Historik Wolf Gruner analyzoval vývoj katalyzovaný teritoriální expanzí nacistického Německa a zároveň uzavíráním možností židovského „vystěhovalectví“. ${ }^{33}$ Masové vypovídání z Německa začalo v roce 1938 skupinou sovětských Židů a pokračovalo násilným vyháněním Židů z Rakouska, které se v prvních týdnech týkalo zejména cizích státních př́íslušníků a lidí bez státního občanství. V Burgenlandu, rakouské spolkové zemi na hranicích s Mad’arskem připojené po první světové válce, nacistické vedení a jednotky SA (Sturmabteilungen) usilovaly o úplné očištění od Židů. Muži SA terorizovali místní Židy a v menších skupinách je posílali přes hranice Československa, Mad'arska a Jugoslávie, respektive vypovídali do Vídně. ${ }^{14}$ Po Mnichovské dohodě a po křřštálové noci podobný osud prožívali Židé z pohraničí českých zemí, tzv. Sudet. ${ }^{15}$

Vyhnání polských Židů, tzv. Polenaktion, předcházelo uzavření hranic evropských zemí pro židovské uprchlíky. Polsko se bezprostředně po „anšlusu“ Rakouska snažilo zabránit návratu polských Židů žijících v zahraničí a kromě administrativních opatření přistoupilo k revizi jejich občanství. Právě ta se stala podnětem pro nacistické deportace 27. - 29. ř́ijna 1938. Překvapeným rodinám doručovali policisté, často brzy ráno, vypovídací dekrety a okamžitě je odváděli

11 Archív mesta Bratislavy (AMB), f. Mestský notárský úrad (1923 - 1945), č. j. 3518/38, Nařízení Prezídia Krajinského úřadu v Bratislavě, 2. listopadu 1938; NIŽŇANSKÝ 2001, dokument č. 109, s. 228.

12 NIŽŇANSKÝ 1999, s. 36-43.

13 GRUNER, Wolf. Von der Kollektivausweisung zur Deportation der Juden aus Deutschland (1938 - 1945). Neue Perspektiven und Dokumente. In DIECKMANN Christoph - KUNDRUS, Birthe - MEYER, Beate (eds.) Die Deportation der Juden aus Deutschland. Pläne, Praxis, Reaktionen 1938 - 1945. Göttingen : Wallstein, 2004, s. 21-62.

14 ZALMON, Milka. Forced emigration of the Jews of Burgenland: A test case. In Yad Vashem Studies, 2003, roč. 31, s. 287-323; TSCHÖGL, Gert - TOBLER, Barbara - LANG, Alfred (eds.) Vertrieben. Erinnerungen burgenländischer Juden und Jüdinnen. Wien : Mandelbaum, 2004; ČAPKOVÁ, Kateřina - FRANKL, Michal. Nejisté útočiště: Československo a uprchlíci před nacismem 1933 - 1938. Praha; Litomyšl : Paseka, 2008.

15 Faktografický souhrn útěku z pohraničí a literatura viz BENDA, Jan. Útěky a vyhánění z pohraničí českých zemí 1938 -1939. Praha : Karolinum, 2013. 
na shromaždiště, odkud byli následně zvláštními vlaky posláni směrem k polské hranici. Deportovaní netušili, co se s nimi stane, a často si s sebou nevzali nebo nemohli vzít ani základní potřeby - někteří byli do vlaků naloženi ještě v pyžamu. ${ }^{16}$ I přes očividnou časovou a kauzální souvislost však Grunner slovenské deportace roku 1938 neřadí do tohoto sledu událostí a soustřed'uje se pouze na vyhánění z nacistického Německa. Jejich analýza proto také nabízí šanci, dynamiku vyhánění a deportací v roce 1938 sledovat transnacionálně a zhodnotit interakci nacistického Německa s národními státy ve středovýchodní Evropě.

Podle Tisova nařízení ze 4. listopadu měly policejní úřady a Hlinkova garda okamžitě zadržet Židy bez hmotných prostředků a ještě do půlnoci téhož dne je postrkem dopravit přes novou hranici, pokud možno do hloubky alespoň několika kilometrů. Ponechat jim měli pouze stravné ve výši 50 korun na osobu, jejich majetek, živnostenské prostory a byty měli zapečetit či uložit. Naopak zámožné židovské obyvatele s majetkem přes půl milionu korun měly úřady zajistit. Nařízení se teoreticky nevztahovalo na Židy s cizím občanstvím, ovšem s výjimkou polských, mad'arských, rumunských a německých občanů, čímž do jeho působnosti spadala většina cizích Židů žijících na Slovensku. ${ }^{17}$ První nařízení kategorizovalo Židy na Slovensku především podle sociálního statusu: bylo vedeno představami o Židech, kteří slovenské společnosti připadají na obtíž, a zároveň mělo zabránit vyvážení židovského majetku. Korespondovala s oběma stranami dobových protižidovských předsudků - na jedné straně vykreslování nemajetných, cizích a nepříslušejících „východních Židů“ a na straně druhé majetných Židů, kteří se obohatili na práci prostého slovenského lidu. Obava z vývozu židovského majetku navíc náležela do antisemitského repertoáru druhé Československé republiky.

Nařízení, jež předpokládalo deportaci vlastních občanů, bylo zcela bezprecedentním krokem: ještě týž večer proto policejní ředitelství telefonovalo upravenou instrukci, která - při zachování deportací jako takových - převracela logiku výběru. ${ }^{18}$ Do odstoupeného území (nejméně do vzdálenosti 20 kilometrů od hranice) měli být nyní deportováni židovští cizinci - „pol'skí, mad’arskí atd'“" a „bezdomovci“ (lidé bez státní příslušnosti). ${ }^{19}$ Nařízení se nadále týkalo těch československých židovských občanů, kteří bydleli mimo svou domovskou obec: ti však neměli být

16 TOMASZEWSKI, Jerzy. Auftakt zur Vernichtung. Osnabrück : Fibre, 2002; BOTHE, Alina - PICKHAN, Gertrud - MEIBECK, Christine (eds.) Ausgewiesen! Berlin, 28. 10. 1938. Die Geschichte der "Polenaktion“. Berlin : Metropol, 2018; MAURER, Trude. Abschiebung und Attentat. Die Ausweisung der polnischen Juden und der Vorwand für die "Kristallnacht". In PEHLE, Walter H. (ed.) Der Judenpogrom 1938. Von der "Reichsristallnacht" zum Völkermord. Frankfurt am Main : Fischer Taschenbuch, 1988; MILTON, Sybil. The Expulsion of Polish Jews from Germany, October 1938 to July 1939: A Documentation. In Leo Baeck Institute Year Book, 1984, roč. 29, s. 169-199; MILTON, Sybil. The Expulsion of Polish Jews from Germany. October 1938 to July 1939. A Documentation. In MARRUS, Michael Robert (ed.) The origins of the Holocaust. Westport : Meckler, 1989; HARRIS, Bonnie M. From German Jews to Polish refugees: Germany's "Polenaktion" and the Zbaszyn deportations of October 1938. In Kwartalnik Historii Żydow, 2009, č. 2 (230), s. 175-205.

17 USHMM, f. RG-57.007M, Selected records from the State Regional Archive in Modra, Slovak Republic, reel 1, Záznam fonogramu, Okresní úřad Modra, 4. listopadu 1938, 12 hod.; NIŽŇANSKÝ 2001, dokument č. 110, s. 228-230.

18 Podle Nižňanského mohla být tato změna důsledkem intervence presidiálního šéfa slovenského ministerstva vnitra Izidora Kosa u Tisa. NIŽŇANSKÝ 1999, s. 40-41.

19 USHMM, f. RG-57.007M, Selected records from the State Regional Archive in Modra, Slovak Republic, reel 1, Záznam fonogramu, Okresní úřad Modra, 4. listopadu 1938, 20:50 hod; NIŽŇANSKÝ 2001, dokument č. 111, s. 230. 
deportováni na jižní Slovensko, ale urychleně vypovězeni (což ale neznamenalo okamžité fyzické odstranění) do domovských obcí. Tato instrukce se bezpochyby vztahovala zejména na Židy z Podkarpatské Rusi, ale bylo možné ji aplikovat také na ty z českých zemí. Večer se tedy již základním kritériem stává - místo sociálního postavení - občanství. Tím se slovenské deportace také více podobaly vypovězení polských Židů z nacistického Německa, které se týkalo polských občanů, již měli být zbaveni občanství. Polští občané či Židé původně z Polska také tvořili největší skupinu deportovaných ze Slovenska - jejich vypovídání do Mad'arska bylo jedním z mnoha nepromyšlených aspektů slovenské akce.

Měnící se a nejasně definovaná pravidla, navíc sdělovaná pouze telefonicky, měla za následek chaotický průběh deportací, jež si úředníci, policisté i gardisté vykládali různým způsobem. Okresní úřad v Ilavě například konstatoval, že „[d]ané pokyny neboly dost' jasné a bolo preto z počiatku hod'ne vzájomného telefonovania medzi okresnými úradmi, jako treba telefonogramom rozumet', menovite či sa pokyn týka len židov štátnej prislušnosti pol'skej, nemeckej, rumunskej a mad'arskej alebo aj židov štátnej príslušnosti česko-slovenskej. ${ }^{20}$ Zmatené instrukce a chaotický průběh nesvědčí pouze o nedostatku přípravy, ale také o tom, že - podobně jako deportace polských Židů z nacistického Německa jen o několik dní dříve, byly přechodem mezi vyháněním skupin Židů, kteří byli svévolně vyváženi na hranice, a hromadnými transporty.

Již 7. listopadu kolem poledne, po třech dnech, však Tiso nařídil „akciu premiest'ňovania Židov likvidovat'“. ${ }^{21}$ Od pátečního - šabatového - večera (4. listopadu) do zastavení akce stačilo četnictvo a Hlinkova garda zadržet a deportovat přibližně 4000 Židů. ${ }^{22}$ Ovšem ukončeny byly jen masové deportace na jižní Slovensko: nařízení krajinského úradu z 8. listopadu, které Tisův rozkaz systematizovalo a zpětně uvádělo do souladu s československým právem, zároveň indikovalo další vyhoštování Židů. Místo plošného odstraňování měly ale úřady postupovat v souladu s existujícími zákonnými normami o pobytu cizinců a zbavovat se zejména nemajetných Židů. Z československých občanů měli být vypovídáni do domovských obcí pouze nemajetní Židé příslušní na Podkarpatskou Rus. Aniž by to bylo

20 SNA, f. KÚ BA, k. 309, č. j. 70081/38, Hlášení okresního úřadu Ilava, 10. listopadu 1938.

21 SNA, f. KÚ BA, k. 309, č. j. 70081/38, Zápis, dr. Klinovský, 7. listopadu 1938; NIŽŇANSKÝ 2001, dokument č. 113, s. 231.

22 Dobové odhady počtu deportovaných fluktuují, od zhruba 2000 po 10 000, a ukazují nesystematičnost a chaotický ráz celé akce. Eduard Nižňanský na základě zpráv a seznamů deportovaných (SNA, f. KÚ BA, k. 309, sign. P IV-cudz.) došel k souhrnnému číslu přesahujícímu 7500 deportovaných. (Nižňanský 1999, 76-79 a 254-255). Toto číslo však nemůže být správné, protože zahrnuje údaj o 4000 deportovaných z Bratislavy založený na hlášení Policejního ředitelství v Bratislavě z 9. listopadu 1938 (SNA, f. KÚ BA, k. 309, č. j. 71525/38); NIŽŇANSKÝ 2001, dokument č. 115, s. 233-234), jež zpravuje o telefonátu zahraničního novináře. Ten se měl 5. listopadu dotazovat, zda je pravdivý údaj o 14 tisících deportovaných - údajně měl od bratislavské policie dostat odpověd', že skutečný počet deportovaných pro celé Slovensko je 4000 osob. Ovšem týž den poslal policejní ředitel zprávu o prủběhu deportací (tamtéž), podle níž bylo v Bratislavě zadrženo a na obsazené území odesláno pouze 260 osob. Je proto vysoce pravděpodobné, že se zpožděním formulovaná zpráva o rozhovoru s novinářem obsahuje zavádějící formulaci - číslo pravděpodobně mělo odkazovat na celkový počet deportovaných (který ale ještě 5. listopadu nemohli v Bratislavě znát, v době odeslání zprávy však již ano). Informace o 4000 deportovaných jen z Bratislavy se zdá vysoce nadsazená též s ohledem na celkový počet židovských obyvatel města (zhruba 15 tisíc podle sčítání z roku 1930), a i proto, že by takto rozsáhlá akce musela zanechat větší stopu v úředních dokumentech, v pramenech židovské provenience i v egodokumentech. Ačkoli přesné číslo postižených z celého Slovenska není možné zjistit, lze vycházet z počtu přibližně 4000 osob. 
explicitně řečeno, předpokládalo nařízení návrat československých občanů, kteří byli - alespoň z některých okresů - také deportováni. Úřady měly těmto lidem vracet zajištěné peníze a cennosti „pokial' snád’ sa zdržujú v blízkosti zaistených vecí", případně je dát do úschovy oprávněným zástupcům. Podobné předpisy se týkaly zapečetěných bytů a živností. Naopak ostatní deportovaní se oficiálně nesměli vrátit přes nové hranice. Jejich živnosti měly být likvidovány spolehlivými důvěrníky. ${ }^{23}$

Přesně měsíc trvalo, než týž úřad reguloval také nepř́íjemné téma návratu. Nařízení z 8. prosince konstatovalo, že mad'arské úřady pochytaly a dovezly k demarkační čáře několik set vypovězených Židů (cizího občanství). Okresní náčelníci měli deportované v zemi nikoho přezkoumat z hlediska státní příslušnosti a převzít pouze ty z nich, kteří před deportacemi pobývali na území zmenšeného Slovenska a příslušeli na Slovensko, do Čech, na Podkarpatskou Rus nebo do Polska. Převzetí se naopak netýkalo mad’arských příslušníků - je však pozoruhodné, že ti v nařízení nebyli nijak definováni. Mohlo to souviset s tím, že ustanovení ohledně státní příslušnosti měla teprve později řešit zvláštní československo-mad'arská komise. ${ }^{24}$ Dosavadní českoslovenští občané př́slušní do okresů odstoupených Mad'arsku byli v praxi považováni za mad’arské občany (byt' ve skutečnosti v Mad'arsku nezískali automaticky občanství). Židé převzatí ze země nikoho a příslušní do Čech, na Podkarpatskou Rus nebo do Polska měli být odstrčeni do svých domovských obcí v těchto zemích. Ostatní - tzn. zejména lidé bez státní příslušnosti - měli být podle nařízení soustředěni ve zvláštním táboře na odlehlém místě tak, aby nepřicházeli do styku s ostatními obyvateli a aby se omezilo riziko šíření nemocí. Měli být pečlivě evidováni a kvůli špatnému hygienickému stavu po pobytu mezi liniemi dezinfikováni. ${ }^{25}$

Měsíc mezi nařízením z 8. listopadu a 8. prosince 1938 tvořil časový rámec země nikoho, šedou zónu charakterizovanou nejistotou a ilegálními praktikami - nejen vypovězení, ale i představitelé slovenských úřadů často nevěděly, jaký postup je správný. ${ }^{26} \mathrm{~K}$ nejasným nařízením, teprve se formující hranici a nové struktuře státní správy patřil také neoprávněný, ale často potichu tolerovaný návrat deportovaných. Zprávy z jednotlivých okresů přibližují spontánní rozhodnutí mnoha deportovaných ve chvíli, kdy byly deportace zastaveny. Očividně fungovala „šeptanda“ - neoficiální informace a zkušenosti, jež si vypovězení vyměňovali. Např́lklad podle zprávy z Bánovců nad Bebravou „boli vyhostenci informovaní v súsedných [!] okresoch - že vystáahovanie sa netýka židov príslušných do niektorej

23 SNA, f. KÚ BA, k. 309, Nařízení Krajinského úradu v Bratislavě, 8. listopadu 1938; USHMM, f. RG-57.011, Okresný úrad Prešov, k. 16, sign. 224/1939, NIŽŇANSKÝ 2001, dokument č. 114, s. 232-233.

24 Dohoda o úpravě státního občanství a opce mezi Československem a Mad'arskem byla uzavřena až 18. února 1939, přičemž pro československé občanství mohli optovat pouze obyvatelé české, slovenské a rusínské národnosti. Viz DEÁK, Ladislav (ed.) Viedenská arbitráž - 2. november 1938. Dokumenty III., rokovania (3. november 1938 - 4. apríl 1939). Martin: Matica Slovenská, 2005, s. 288-293.

25 SNA, f. KÚ BA, k. 309, č. j. 77581/38, Nařízení Krajinského úradu v Bratislavě, 8. prosince 1938; USHMM, f. RG-57.011, Okresný úrad Prešov, k. 16, sign. 224/1939, Nařízení Krajinského úradu v Bratislavě, 8. prosince 1938; NIŽNANSKÝ 2001, dokument č. 116. s. 234-236.

26 Okresnímu úřadu v Bardejově bylo např́iklad nejasné, zda se nařízení z 8. listopadu týká i Židů bez státní příslušnosti - hovořilo se tam pouze o cizích příslušnících. SNA, f. KÚ BA, k. 309, č. j. 70414/38 prez., Hlášení okresního náčelníka v Bardejově, 28. listopadu 1938. 
obce Slovenska, pokial obec nepripadne Mad'arsku a preto sa vyhostení zase vracali zpät.".27 I před oficiálním povolením se tak pravděpodobně velká část deportovaných vrátila na území zmenšeného Slovenska, většinou do svých původních bydlišt'. Nebyli mezi nimi pouze českoslovenští občané odstranění podle prvního nařízení ze 4. listopadu, ale také lidé s jinou státní přrislušností, zejména polští občané, a ti bez doloženého občanství.

Pokud se vrátili ještě před ukončením deportací, mohli být znovu posláni na jih: např́klad ze 40 lidí deportovaných z Banské Bystrice $\mathrm{k}$ Lučenci se během dvou dnů, podle zjištění okresního úřadu, do města vrátili čtyři lidé. Za pomoci Hlinkovy gardy byli opět, ještě před madarskou okupací, vyvezeni stejným směrem. ${ }^{28}$ Jen o něco později však situace vypadala jinak, podle zprávy okresního úřadu se již do 19. listopadu svévolně vrátilo na 70 \% z 292 vypovězených Židů z okresu Michalovce. Ty hodlal okresní úřad v souladu s nařízeným postupem vypovídat, což v praxi naráželo na těžkosti. Většina z nich byla bez státního občanství, a jejich odstraňování proto bylo možné pouze ilegálně - to ale většinou nešlo uskutečnit kvůli početným rodinám s malými dětmi. $\mathrm{Z}$ tohoto důvodu okresní náčelník navrhoval těmto Židům odebírat živnostenská a obdobná oprávnění tak, aby byli nuceni se sami vystěhovat. ${ }^{29}$ Např́íklad zpět do Banské Bystrice bylo 3. prosince 1938 dopraveno 14 deportovaných s polským občanstvím - z nich byli dva ihned vypovězeni, dva vyzváni k opuštění Slovenska a ostatní byli ponecháni ve městě, kde již mnoho let pobývali. ${ }^{30}$ Do Spišské Staré Vsi se všech 28 vyvezených osob do tří dnů vrátilo. Všichni byli polští občané, které však Polsko zbavilo občanství kvůli dlouhému pobytu v zahraničí. ${ }^{31}$

\section{Země nikoho v pohybu}

Egon Schwarz byl v noci spolu s rodiči deportován na korbě nákladního vozu, z nějž je jejich nemluvní strážci ve spěchu a beze slov vyložili uprostřed městečka na náměstí, bez jakéhokoli vybavení a bez prostředků. Dunajská Streda, kde se ocitli, byla již polepena mad’arskými nápisy oslavujícími návrat do Mad’arska. Přesto - nebo možná právě proto, jako obětem (česko)slovenského pronásledování - jim obyvatelé poskytli pomoc: jídlo, deky, nářadí a stany. Egon u místních za stravu pomáhal štípat dř́ví na zimu. $V$ době bezvládí, po odchodu slovenských úřadů a před etablováním mad’arské moci, mohla skupina deportovaných nepředstavitelné: prostě stanovala na náměstí, ${ }^{32}$ kde stála velká synagoga z roku 1865 , jež mohla pojmout na 800 věŕících. Země nikoho nebyla tedy statická: v době evakuace a předávání mezi 5. a 10. listopadem jako by se celé jižní Slovensko stalo

27 SNA, f. KÚ BA, k. 309, č. j. 70081/38 prez., Hlášení okresního náčelníka Bánovce nad Bebravou, 9. listopadu 1938.

28 SNA, f. KÚ BA, k. 309, č. j. 2600/38 prez., Hlášení okresního náčelníka Banská Bystrica, 8. listopadu 1938. 29 SNA, f. KÚ BA, k. 309, č. j. 70014/18 prez., Hlášení okresního úřadu v Michalovcích, 19. listopadu 1938. 30 SNA, f. KÚ BA, k. 309, č. j. 77581/38 prez., Hlášení okresního náčelníka Banská Bystrica, 11. ledna 1939. 31 SNA, f. KÚ BA, k. 309, č. j. 77581/38 prez., Hlášení okresního náčelníka Spišská Stará Ves, 3. února 1939. 32 SCHWARZ 2009, s. 65-67. 
jakousi zemí nikoho, v níž panovalo bezvládí a v níž se střetávali různí aktéři, jejichž pravomoci byly často nejasné. ${ }^{33}$

Tento fenomén lze dobře ilustrovat na průběhu deportací do Košic a jejich okolí. Podle zprávy, jež neznámým způsobem v překladu doputovala do židovské pomocné organizace American Jewish Joint Distribution Committee (JDC, JOINT), zavládla v Košicích po první Vídeňské arbitráži nejistota a místní Židé v obavě z nájezdů Hlinkovy gardy zabarikádovali obchody, postavili stráž před synagogu a svitky Tóry přesunuli do bezpečí. V sobotu 5. listopadu přivezli místní automobilisté zprávu, že asi 15 kilometrů od města bylo vyloženo na 60 uprchlíků, kteří jsou bez jídla a peněz. Tam je údajně našla náhodně kolem táhnoucí jednotka československého vojska - zatímco čeští vojáci se s nešt’astníky měli podělit o jídlo, slovenští jim je měli zase odebrat. Právě slovenští vojáci měli násilím zabránit výpravě košických Židů, aby této skupině dopravili pomoc. Teprve o den později vyhnané skupině povolila československá armáda vstup do města. $V$ neděli 6 . listopadu, $\mathrm{v}$ době evakuace slovenských úřadů, přivezli automobilisté zprávu, že skupina starších Židů byla Hlinkovou gardou vysazena na křestanském hřbitově za městem a že další skupiny jsou rozptýleny po lesích.

Místní židovská komunita, ve spolupráci s Mad’arskou národní radou, rychle spustila improvizovanou pomocnou akci: 15 aut soustavně prohledávalo okolí města a hledalo skupiny vypovězených - postupně takto do Košic svezli na 700 deportovaných, mezi nimiž bylo i třicet „árijcü“. Od nich se košičtí Židé dozvídali o nečekané deportaci, která postihovala starce i kojence - jedna žena prý dokonce na nákladním voze porodila dvojčata. Muži z Mad’arské národní rady se prý snažili transporty zastavit, a dokonce se jim to alespoň v jednom případu po fyzické potyčce (",hand to hand fight") zdařilo. ${ }^{34} \mathrm{~V}$ Košicích pak zorganizovala židovská obec nejnutnější pomoc: deportované ubytovala v židovské škole a nemocní zcela zaplnili židovskou nemocnici, mnoho uprchlíků si mezi sebe rozebraly židovské rodiny; děti si vzal na starost JDC. Protože byli zcela bez prostředků, zřídila pro ně židovská obec zvláštní polévkovou kuchyni a za pomoci sbírkové akce je ošatila. „V Košicích lze vidět mladé sdané páry, velké rodiny, staré lidi a malé děti, všechny ležící na slámě, dopady jejich krutého osudu zapsané do jejich tváří - lidi, kteří byli smeteni elementární silou mimo jejich kontrolu. ${ }^{135}$ Za pomoci košických Židů se zřejmě mnoho deportovaných ještě před vstupem mad’arské armády vrátilo. Okresní náčelník v Bardejově kvůli tomu hodnotil celou akci jako neúspěch, protože mezitím již byly deportace zastaveny a navrátilce nešlo znovu poslat do odstoupeného území. ${ }^{36}$

33 HLAVINKA 2007, s. 42.

34 Také podle hlášení okresního náčelníka v Sabinově, 9. listopadu 1938, u Košic na hranicích čekali košičtí Židé s motorovými vozidly, sledovali transporty až na místo vyložení, a odtamtud deportované rychle odváželi do Košic. SNA, f. KÚ BA, k. 309, sign. P IV-cudz.

35 Archives of the American Jewish Joint Distribution Committee (JDC Archives), f. New York Office 1933 44, file 541, Victims of Fate, 28. 11. 1938.

36 SNA, f. KÚ BA, k. 309, č. j. 1291/38 prez., Hlášení okresního náčelníka v Bardejove, 9. listopadu 1938. 
Okamžitě po ustavení mad’arské vojenské správy byli Židé, kteří nepříslušeli do Mad’arska, včetně zabraného jižního Slovenska, vraceni na slovenské územín ${ }^{37}$ a prostor pro zemi nikoho se zúžil na samotnou demarkační čáru, která zahrnovala široký pruh území a jejíž každodenní fungování se teprve rodilo. Ta měla být tři kilometry široká, aby se zabránilo nezamýšleným konfliktům mezi oběma armádami. $V$ tomto prostoru zřejmě existovala řada míst, $v$ nichž byly zachyceny menší nebo větší skupiny židovských uprchlíků, o nichž máme pouze útržkovité informace. Jen zmínkami se dozvídáme například o skupině Židů z prešovského okresu, kteří se se shromáždili u mlýna u Nižného Olčváru, východně od Košic, a o něž se zřejmě staralo židovské pohřební bratrstvo (a zároveň charitativní spolek) Chevra kadiša. ${ }^{38} \mathrm{~V}$ opuštěném mlýně na demarkační čáře v okresu Krupina mělo již živořit 32 Židů vypovězených z okresu Námestovo. Kromě Mad’arska a odstoupeného území měla část z nich příslušet do Polska a do Německa. ${ }^{39} 0$ několik dní později se okresní úřad dotazoval, zda by jistému rabínovi z Námestova, který byl mad’arským občanem a již 12 dní se nacházel na demarkační čáře, nemohl být „poskytnutý asyl v Nitre“.40

Ve stejnou dobu se podobné události objevují i u dalších hranic, které byly předmětem teritoriálních revizí. Na (česko)slovensko-polské hranici je známý případ u obce Skalité (okres Čadca). Tam polští pohraničníci Židy deportované z ilavského a púchovského okresu čtyřikrát po sobě vrátili a skupina již byla zcela promrzlá a bez jakýchkoli zásob. ${ }^{41}$ Podobné tragédie se ale zároveň odehrávaly také na pomnichovské demarkační linii mezi Československem a nacistickým Německem obsazeným pohraničím českých zemí, a to zejména po křištálové noci (v „Sudetech" většinou od 10. listopadu). Například na demarkační linii před městem Louny více než tři týdny živořila skupina uprchlíků z Žatce a Kadaně. Třináct lidí ve věku od 23 do 80 let žilo u polní cesty ve stanu a maringotce. ${ }^{42}$ Ve stejnou dobu vzniká také země nikoho v městečku Zbąszyń (Bentchen), na polské straně německo-polské hranice. Zde zpočátku žilo kolem 7000 deportovaných polských Židů, jež polská vláda odmítala vpustit do země a kteří byli nouzově ubytováni v kasárnách, rozpadajícím se mlýnu, ale také v běžných domech. Jejich počet se postupně snižoval, ale teprve v létě 1939, těsně před invazí nacistického Německa, jim úřady povolily vstup do země.

Tábořiště u Miloslavova a Velkého Kýru zřejmě brzy začala fungovat jako jakási ohniska, do nichž civilní úřady a armáda - mad’arské, ale výjimečně též česko-

37 POTEMRA, Michal. Židovská otázka v Košiciach v rokoch 1938 - 1944. In JUROVÁ, Anna - ŠALAMON, Pavol (eds.) Košice a deportácie Židov v roku 1944. Košice : Spoločenskovedný ústav SAV Košice/ Oddelenie židovskej kultúry Slovenského národného múzea v Bratislave, 1994, s. 41-42.

38 SNA, f. KÚ BA, k. 309, č. j. 77581/38 prez., Zpráva okresního úřadu v Prešově, 30. ledna 1939; NIŽŇANSKÝ 2001, dokument č. 163, s. 299-300.

39 SNA, f. KÚ BA, k. 309, č. j. 72289/38 prez., Telefonické hlášení okresního náčelníka v Krupině, 16. listopadu 1938.

40 SNA, f. KÚ BA, k. 309, č. j. 73971/38 prez., Telefonické hlášení komisaře Hanulíka, okresní úřad v Krupině, 23. listopadu 1938.

41 SNA, f. KÚ BA, k. 309, č. j. 70220/38 prez., Telefonické hlášení okresního náčelníka Čadca, 7. listopadu 1938.

42 Archiv Židovského muzea v Praze (AŽMP), sbírka Walter Ullmann; YIVO Archives, New York; JDC Archives, f. New York Office 1933 - 1944, file 541. 
slovenské - začaly soustřed’ovat deportované, kteří se nacházeli jinde v prostoru demarkační čáry nebo za ní. Schwarz například zaznamenal příjezd československého vojenského džípu, který do Miloslavova přivezl židovskou rodinu nalezenou jinde: rodiče a dva mrazem zmodralé kojence, $\mathrm{z}$ nichž jeden jen o několik hodin později zemřel. ${ }^{43}$ Ačkoli nejsou známa přesná data, obě koncentrace vyhnanců vznikly zřejmě kolem 10. listopadu, po obsazení odstoupeného regionu mad’arskou armádou. Shromáždění uprchlíků v těchto místech nebylo podle všeho důsledkem rozhodnutí či plánů úřadů, ale utvořila se postupně z praxe vypovídání deportovaných krátkou cestou zpět na Slovensko. Jejich lokace ale nebyla ani úplně náhodná, nebot' vyplývala z geografie deportací a struktury komunikací, po nichž byli vypovězení odsouváni, a to oběma směry. Velký Kýr se nacházel na demarkační linii na silnici mezi Nitrou a Novými Zámky, přičemž tímto směrem byli deportováni Židé z komunit na sever od Nitry - dokumentována jsou místa původu například v Bánovcích nad Bebravou, Prievidzi, Hlohovci, Topolčanech či Pieštanech. Miloslavov vznikl poblíž silnice a železniční trati mezi Bratislavou a Dunajskou Stredou - právě tímto směrem byli deportováni bratislavští Židé, ale např́íklad - podle fragmentárních dokladů - také ti z Malacek a Pezinku. Tato geografie deportací a formující se země nikoho také souvisela s časovým tlakem a snahou o provedení deportací co nejkratší možnou cestou. Není ale asi také náhodou, že všechna tři centra, do jejichž okolí deportace směřovaly - Košice, Nové Zámky a Dunajská Streda - měly významné a početné židovské obce.

Ke komplexní geografii země nikoho přispíval také multietnický charakter hraničního regionu. Například Beatrice Wellington, kanadská aktivistka pomáhající uprchlíkům v pomnichovském Československu, se při cestě z Bratislavy za uprchlíky za Miloslavovem podivovala nad jazykovou rozmanitostí: „Ve třech vesničkách jsme zastavili, abychom se zeptali na cestu. V první se mluvilo mad'arsky, ve druhé německy; ve třetí slovensky [...]" Pro slovenské politiky a úředníky však tato rozmanitost nebyla překvapivá - naopak byla po desetiletí předmětem sporů a národnostních konfliktů. Slovenští nacionalisté argumentovali nucenou mad'arizací, proti které se po vzniku Československa snažili působit například vlastním sčítáním lidu nebo usazováním slovenských kolonistů, zejména v kontextu československé pozemkové reformy. Samotný Miloslavov vznikl spojením dvou kolonií českých a slovenských rodin (z Volyně, Jugoslávie a Mad'arska). Naopak po první Vídeňské arbitráži byli nedávno usazení „kolonisté“ z jižního Slovenska masově vyháněni, často za použití násilí a bez možnosti přestěhovat svůj majetek. ${ }^{44}$

Ani počet lidí v těchto dvou případech země nikoho není dobře zdokumentovaný a navíc většina dostupných informací pochází z pozdější doby, respektive z doby jejich likvidace. Je pravděpodobné, že jak u Miloslavova, tak i u Velkého Kýru bylo

43 SCHWARZ 2009, s. 71.

44 RISTVEYOVÁ, Katarína. Migrácia Slovákov a Čechov z južného Slovenska po viedenskej arbiráži (s dôrazom na región Žitného ostrova). In ŠMIGEL', Michal - TIŠLIAR, Pavol a kol. Migračné procesy Slovenska (1918 1948). Banská Bystrica : Belianum, 2014. K jižnímu Slovensku po první Vídeňské arbitráži viz též ŠMIHULA, Daniel (ed.) Viedenská arbitráž v roku 1938 a jej európske súvislosti. Zborník príspevkov z vedeckej konferencie. Bratislava : Úrad vlády Slovenskej republiky, 2008; HETÉNYI, Martin. Slovensko-mad’arské pomedzie v rokoch 1938 - 1945. Nitra : Filozofická fakulta Univerzity Konštantína Filozofa, 2008; VIETOR, Martin. Dejiny okupácie južného Slovenska 1938 - 1945. Bratislava : Vydavatel'stvo Slovenskej akadémie vied, 1968. 
v prvních dnech zachyceno kolem 500 lidí, z nichž naprostá většina byli deportováni jako Židé. ${ }^{45}$ U Velkého Kýru, o němž máme (snad kvůli větší vzdálenosti od Bratislavy) mnohem méně informací, mělo na konci listopadu podle bratislavské ortodoxní židovské komunity živořit 344 lidí (132 mužů, 73 žen a 139 dětí). U Miloslavova žilo na konci listopadu 302 vyhnanců, z toho 122 mužů, 77 žen a 103 dětí různého věku, včetně kojenců. ${ }^{46}$ Dne 6. prosince mělo být ještě v Miloslavově na 250 lidí $^{47}$ a Beatrice Wellington, která skupinu u Miloslavova navštívila těsně před koncem existence této země nikoho, zde našla 253 osob. ${ }^{48}$ Zhruba ve stejnou dobu tam však okresní velitelství v Šamoríně napočítalo již jen 190 lidí (108 mužů, 40 žen a 42 dětí). ${ }^{49}$ Postupné, nikým důsledně nekontrolované, snižování počtu „obyvatel“ země nikoho není nikde oficiálně vysvětleno a zdokumentováno. Bylo očividně důsledkem útěku, občasného propouštění a také úmrtnosti - Egon Schwarz informuje o starých či slabých lidech, kteří během prvních, nejtěžších dnů nevydrželi pobyt na poli bez jakékoli ochrany. ${ }^{50}$ „Byli jsme [...] osudem svedeným zástupem [zusammengewürftelte Schar, M. F.], pro nějž by bylo obtížné najít společný úřední jmenovatel", reflektoval Schwarz rozmanitost skupiny, která se sešla na poli za Miloslavovem: byli tam „Mad’aři“ žijící celý život v Bratislavě, „Slováci“ v Mad’arsku, němečtí a rakouští sociální demokraté, kteří utekli do Československa, Židé z Vídně, Berlína, Kolína nad Rýnem a Breslau; vzdělaní i ti, kteří neprošli školami, lidé asimilovaní i ti v kaftanech a s pejzy. Bylo tam možné slyšet němčinu i jidiš, slovenštinu i mad'arštinu. ${ }^{51}$ Přinejmenším na poli u Miloslavova však je doložena také přítomnost dvou romských dětí - bez jakékoli informace o tom, jak se tam dostaly. ${ }^{52}$ Zatímco Schwarz zdůrazňoval pluralitu prostřednictvím jazykových, kulturních a politických identit, aktivisté pomocných organizací ji vyjadřovali především skrze občanství. Nadpoloviční většina z nich měli být lidé bez státního občanství, zatímco menší skupiny příslušely na Slovensko, do Mad’arskem zabraného území, na Podkarpatskou Rus, do Polska a do Německa. ${ }^{53}$

45 SCHWARZ 2009, s. 70; Schmolka uvádí nepřímou informaci o 470 osobách ve Velkém Kýru. USHMM, f. RG-59.006M, Foreign Office: General Correspondence, FO 371/21588, Report by Mrs. Marie Schmolka, manageress of "HICEM" Prague on her visit to the camp at Mischdorf near Bratislava on November 27th, 1938. Zpráva je dostupná též v dalších archivech pomocných organizací, přepis byl publikován v HEUMOS, Peter. Flüchtlingslager, Hilfsorganisationen, Juden im Niemandsland. Zur Flüchtlings- und Emigrationproblematik in der Tschechoslowakei im Herbst 1938. In Bohemia, 1984, roč. 25, č. 2, s. 245-275, zde 272-275; téměř úplný slovenský překlad v NIŽŇANSKÝ 1999, s. 54-56. Viz též FRANKL. Michal. Reports from the No Man's Land. In EHRI Document Blog, January 19, 2016. Dostupné na internetu: https://blog.ehri-project.eu/2016/01/19/ reports-from-the-no-mans-land/.

46 SNA, f. KÚ BA, k. 309, č. j. 77581/38 prez., Žádost ústřední kanceláře ortodoxních židovských obcí, 29. listopadu 1938. Podle hlášení mad’arské armády ze stejné doby tam mělo pobývat 310 osob, z toho 150 mužů, 100 žen a 60 dětí (mad'arští vojáci zřejmě používali jiné měřítko pro kategorizaci „dětí"). GRÜNFELDOVÁ, Diana. Holokaust v okrese Šamorín 1938 - 1945. Bratislava : Univerzita Komenského v Bratislave [Diplomová práca], 2018 , s. 30.

47 SNA, f. KÚ BA, k. 309, č. j. 77581/38 prez., Hlášení okresního náčelníka v Bratislavě, 6. prosince 1938.

48 National Archives, London (NA), f. HO 294, file 53 (Prague correspondence), Zpráva Beatrice Wellington, 17. prosince 1938.

49 GRÜNFELDOVÁ 2018, s. 32.

50 SCHWARZ 2009, s. 71.

51 Tamže, s. 90.

52 NA, f. HO 294, file 53 (Prague correspondence), Zpráva Beatrice Wellington, 17. prosince 1938.

53 SNA, f. KÚ BA, k. 309, Žádost ústřední kanceláře ortodoxních židovských obcí, 29. listopadu 1938. Podobnou statistiku uváděla též Wellington: „The number of people in the camp is 253 (of which 148 were stateless), and of the others: a) 25 were born in NOW Hungary but had lived in NOW Slovakia; b) 11 were born in NOW Slovakia and had lived in NOW Hungary; c) 60 were Germans and Poles. d) 1 was Hungarian; 8 were foreign mixtures without passports." NA, f. HO 294, file 53 (Prague correspondence), Zpráva Beatrice Wellington, 17. prosince 1938. 


\section{Za hranicemi občanství}

Společnost v zemi nikoho byla charakteristická absencí ustálených pravidel či zákonů a pevných, předem existujících, společenských struktur. Ačkoli to by bylo do jisté míry možné tvrdit téměř o každém nuceném společenství, například v ghettech, země nikoho se od nich ve významných aspektech odlišovala. Nemůže být proto směšována s internačními nebo uprchlickými tábory, jaké vznikaly např́ílad v habsburské monarchii během první světové války, tábory pro sociálnědemokratické a komunistické uprchlíky z Rakouska v roce 1934 či tábory pro uprchlíky utíkající s pohraničí českých zemí po Mnichovské dohodě. Ty byly typické podporou uprchlíkủ ze strany státu a pomocných organizací, jež byla kombinována se snahou o jejich kontrolu, často i dalekosáhlou..$^{54}$ I přes všechny rozdíly je charakterizovalo (přinejmenším zamýšlené) podř́zení uprchlíků předpisům regulujícím pohyb uvnitř tábora i mimo něj, strukturujícím prostor i čas, často za pomoci vojensky vypadajících a armádními opatřeními inspirovaných budov a další infrastruktury.

Byt' to může znít překvapivě s ohledem na násilné vyhánění a nasazení policie a armády na obou stranách hranice, země nikoho je naopak charakterizována nepř́tomností státu a jeho silových složek. 0 neexistenci státu uvnitř země nikoho vypovídá též neustálenost pojmů, na niž poukázal též Eduard Nižňanský. V úředních hlášeních byl zpravidla používán pojem "tábor“ doplněný různými př́ívlastky: „koncentrační", „internační", apod. ${ }^{55}$ Naopak pojem země nikoho, preferovaný židovskými pamětníky, pomocnými organizacemi či židovským tiskem, nelze v korespondenci státní provenience téměř nalézt. Ve zkratce podle Jamese C. Scotta: země nikoho nebyla pro stát „čitelná" a zařaditelná. ${ }^{56} \mathrm{Z}$ hlediska státu by totiž zásah uvnitř země nikoho znamenal rozmělnění teritoriální hranice, již si politici, úředníci i vojáci představovali jako jasnou dělící čáru, jež měla být důsledně střežena. Přijetí jakékoli zodpovědnosti za „hranicí by právě takto chápané dělítko, navíc v podobě ještě nestabilní demarkační linie, a v kontextu nejistoty ohledně území, občanství a státoprávního uspořádání, negovalo a narušovalo by deklarovanou jednotu mezi státem jako politickým uskupením, územím a národem (občany).

Složky československého státu tak ve vztahu k vypovězeným za demarkační linii (nebo těch „na čáře“) vystupovaly v režimu pohraničních kontrol a odmítaly uvnitř tohoto prostoru intervenovat. Dokonce i když uprchlíky evidovaly, bylo to pro organizaci hraničního přechodu - aby bylo zřejmé, koho podle nařízení lze přijmout na slovenské území. Nařízení z 8. prosince 1938 například okresním náčelníkům dávalo za úkol přezkoumat totožnost Židů nepřijatých sousedními státy a převzít pouze vybrané skupiny. Nižňanský doložil reakce československých vojenských velitelů na zemi nikoho - zejména tu za Miloslavovem - sahající od sympatií po protižidovské předsudky. Ve shodě však všichni důstojníci zdůrazňovali, že uprchlíci jsou mimo československé území a zodpovědnosti. Viděli je v první řadě jako problém, který

54 FRANKL, Michal. Exhibiting Refugeedom. Orient in Bohemia? Jewish Refugees During the First World War. In Judaica Bohemiae, 2015, roč. 50, č. 1, s. 117-129.

55 NIŽŇANSKÝ 1999, s. 63. Objevuje se též pojem "kolonie".

56 SCOTT, James C. Seeing Like a State. How Certain Schemes to Improve the Human Condition Have Failed. New Haven : Yale University Press, 1998. 
znemožňoval tuto novou, a ještě ne zcela stabilizovanou, hranici střežit a provádět na ní kontrolu. Civilisté, a navíc cizinci, neměli podle armádních plánovačů ve vojenském prostoru, ale dokonce ani v blízkosti hranice, co pohledávat. Vojáci navíc nemohli zcela zabránit ilegálním přechodům a šíření epidemií. ${ }^{57}$ Obávali se, aby při stanovení definitivní hranice židovští uprchlíci nezůstali na československém území. Proto důstojníci naléhali především na rychlé uzavření „tábora“; na konci listopadu dokonce armáda ve snaze je uspíšit dočasně omezila židovské komunitě v Bratislavě možnost zásobování uprchlíků u Miloslavova. ${ }^{58}$

O tomto vztahu k zemi nikoho vypovídá též epizoda reprodukovaná ve Schwarzových vzpomínkách: důstojník československé armády, který přivezl výše zmíněnou rodinu na pole za Miloslavov, se $v$ konfrontaci s realitou v zemi nikoho musel otočit a propukl v hlasitý pláč - s ním tekly slzy i jejím nuceným „obyvatelům“. I přes dojetí pro ně však tento voják více udělat nemohl.$^{59}$ Podle Marie Schmolkové dovolil vojenský velitel odvézt do nemocnice ženu, která celou noc rodila a jejíž výkřiky doháněly uprchlíky k šílenství - ovšem učinil tak na vlastní zodpovědnost, v rozporu s instrukcemi. $^{60}$

Naprosté opuštění v době narůstající zodpovědnosti státu v oblasti sociálního zaopatření a zdravotní péče symbolizovalo také vyloučení z komunity občanů. Uprchlíci byli odkázáni na podporu židovských náboženských obcí a pomocných organizací - lokálních i mezinárodních. Právě materiální a organizační pomoc židovských organizací vůbec umožnila státům takové dalekosáhlé opuštění - bez nich by hrozilo zejména šíření nemocí a vysoká úmrtnost na dohled od pohraničních hlídek. Ačkoli mezi židovskými organizacemi v roce 1938 panoval konsensus o nutnosti pomáhat židovským uprchlíkům, byli si jejich představitelé jistě vědomi dilematu židovské sociální práce v zemi nikoho: ta totiž zároveň potvrzovala vyloučení a zbavování občanství a vytvářela jakousi nedokonalou náhradu občanství národních států.

\section{Zapomenutá a nepojmenovaná}

Zkoumat zemi nikoho zevnitř není jednoduché: pramenů umožňujících nahlédnout do tohoto zvláštního území a této podivné společnosti se dochovalo pouze minimum. Zatímco stovky dokumentů a řada z nich vycházejících prací historiků, respektive edic dokumentů, popisují proces vedoucí k rozhodnutí o deportacích a jejich chaotický průběh, máme jen málo informací o tom, co se s lidmi naloženými na kapotu nákladních vozů stalo a jak vlastní postavení interpretovali. Podobně málo víme o následujících osudech těchto lidí a jejich dalších trajektoriích - pronásledování i útěku.

Jen málo je známo o improvizovaných sociálních strukturách, jež bezpochyby mezi uprchlíky, jako v jakékoli jiné skupině, vznikaly. Schwarz například odkazuje na vůdčí

57 SNA, f. KÚ BA, k. 309, č. j. 77581/38 prez., Podobné obavy vyjadřoval také okresní náčelníkv Bratislavě, hlášení z 6. prosince 1938 .

58 NIŽŇANSKÝ 2001, dokumenty č. 126, 127, s. 252-254.

59 SCHWARZ 2009, s. 71.

60 USHMM, f. RG-59.006M, Foreign Office: General Correspondence, FO 371/21588, Report by Mrs. Marie Schmolka, manageress of "HICEM" Prague on her visit to the camp at Mischdorf near Bratislava on 27th November, 1938. 
postavy, které organizovaly hledání potravin, vody a dalších užitečných věcí na polích $\mathrm{v}$ okolí (uvnitř neutrální zóny). ${ }^{61}$ Téměř ve všech zprávách o návštěvách v zemi nikoho u Miloslavova vystupuje postava vídeňského lékaře, který se stal neoficiálním zástupcem vyhnanců - údajně sám mohl překročit hranici a toto hrůzné místo opustit, ale nechtěl ostatní vyhnance nechat bez pomoci. Naštěstí disponoval (alespoň na konci pobytu) dobře vybavenou „lékarničkou“ a každému rozdal zubní kartáček. ${ }^{62}$ Nicméně skutečná autorita v zemi nikoho přicházela zvnějšku: byla spojena s možností překračovat hranici a dopravovat materiální pomoc, stejně jako s organizací emigrace.

Proto většina známých informací pochází ze zpráv a pozdějších svědectví pracovníků židovských pomocných organizací, případně na nich založených článků v tisku. Mezi ty patří především již vícekrát využitá a zveřejněná zpráva ředitelky československé pobočky organisace HICEM a aktivistky židovské pomocné práce Marie Schmolkové, ${ }^{63}$ a dosud nevyužitá zpráva Beatrice Wellington. ${ }^{64}$ Tyto zásadní prameny ovšem vznikly na základě krátké návštěvy a představují pouze statický snímek dynamického prostoru země nikoho, a to navíc v době, kdy se již situace uprchlíků lepšila (Schmolková v Miloslavově byla 27. listopadu a Wellington dokonce až 18. prosince). Při jedné z těchto příležitostí, snad spolu se Schmolkovou, navštívil tábořiště za Miloslavovem také novinář a fotograf Berthold Birnbach (sám židovský uprchlík z Rakouska), který pořídil vizuálně velmi působivou sérii fotografií; natáčel tam také filmový štáb. Dokonce i vzpomínky Arona Grünhuta, funkcionáře ortodoxní židovské obce v Bratislavě, který organizoval pomocnou akci u Miloslavova, nebo zprostředkované zápisky Oskara Neumanna poskytují pouze částečný obraz. ${ }^{65} \mathrm{Z}$ mad’arské strany se dochovaly podobné zprávy z návštěv funkcionářu židovských obcí v Dunajské Stredě a Šamoríně. ${ }^{66}$

Tyto zprávy zprostředkují obraz lidí v zoufalé situaci, ponechaných mezi pohraničními liniemi, v chladném listopadovém a prosincovém počasí. Schmolková nalezla uprchlíky „na otevřeném poli, v teplotách až 2 stupně pod nulou během dne a až 5 stupňu pod nulou v noci. Postavili si skrovné chaty a přistřešky ze stonků kukuřice a vykopali díry, do nichž uložili děti (některým z těchto dětí je pouze několik měsícu). ${ }^{167}$ Po několika prvních dnech, kdy byli uprchlíci bez jakékoli pomoci, dovolila československá armáda bratislavské židovské komunitě jejich zásobování potravinami a nutnými potřebami. Několik stěhovacích vozů přitažených na pole poskytovalo ochranu ale-

61 SCHWARZ 2009, s. 70-71.

62 Tamže, s. 71; USHMM, f. RG-59.006M, Foreign Office: General Correspondence, FO 371/21588, Report by Mrs. Marie Schmolka, manageress of "HICEM" Prague on her visit to the camp at Mischdorf near Bratislava on $27^{\text {th }}$ November, 1938; NA, f. HO 294, file 53 (Prague correspondence), Zpráva Beatrice Wellington, 17. prosince 1938. 63 USHMM, f. RG-59.006M, Foreign Office: General Correspondence, FO 371/21588, Report by Mrs. Marie Schmolka, manageress of "HICEM" Prague on her visit to the camp at Mischdorf near Bratislava on 27th November, 1938.

64 NA, f. HO 294, file 53 (Prague correspondence), Zpráva Beatrice Wellington, 17. prosince 1938.

65 GRÜNHUT, Aron. Katastrophenzeit des slowakischen Judentums. Aufstieg und Niedergang der Juden von Pressburg. Tel Aviv : Selbstverlag, 1972; NEUMANN, Oskar. Im Schatten des Todes. Ein Tatsachenbericht vom Schicksalskampf des slovakischen Judentums. Tel-Aviv: Edition Olamenu, 1956.

66 GRÜNFELDOVÁ 2018, s. 30-32.

67 USHMM, f. RG-59.006M, Foreign Office: General Correspondence, FO 371/21588, Report by Mrs. Marie Schmolka, manageress of "HICEM" Prague on her visit to the camp at Mischdorf near Bratislava on $27^{\text {th }}$ November, 1938. 
spoň nejzranitelnějším. $V$ této době se také mluvilo o plánech na poli vystavět dřevěné baráky - již koncem listopadu měly prý být z mad’arské strany dodávány stavební materiály. Ke stavbě samotné podle všeho již nedošlo. ${ }^{68}$ Zprávy se také zmiňují o starých lidech, válečných invalidech, lidech s vysokou teplotou a o člověku s krvácením do žaludku. Způsob, kterým humanitární pracovnice popisují situaci a náladu uprchlíků, se ale také trochu liší: zatímco Schmolková ji líčí jako beznadějnou, Wellington též zdůrazňuje „splendid spirits“ lidí, kteř́ - i když bez naděje a vize - prokazovali mimořádnou vytrvalost a na nic si nestěžovali. Tento pohled ale může být ovlivněn tím, že uprchlíky navštívila $v$ době těsně před jejich přesunem do Bratislavy, o němž již „obyvatelé“ země nikoho mohli vědět. ${ }^{69}$

Ovšem v žádném z těchto dokumentů nehovoří uprchlíci přímo a zůstávají anonymní. Dokonce ani zmiňovaný lékař není nikde označen jménem. Tato absence hlasu uprchlíků samotných je patrná také na pozdějších pamět'ových dokumentech. Vzpomínky Egona Schwarze zůstávají jediným obsáhlejším svědectvím o životě na poli za Miloslavovem a k dalším zemím nikoho na slovensko-mad’arské linii zatím nebylo nalezeno nic srovnatelného. Autorovi se dosud podařilo identifikovat jen malý počet orálněhistorických rozhovorů s lidmi, kteří byli v zemi nikoho na jižním Slovensku (na rozdíl od Zbąszyně). To jistě souvisí i s nedostatkem znalostí o zemi nikoho na straně tazatelů, kteří nekladli doplňující otázky, a katalogizátorů, kteří opatřovali rozhovory metadaty. Výpovědi v identifikovaných rozhovorech jsou většinou velmi stručné: např́klad tehdy šestiletý Isidor Pinkasovič vzpomínal pouze na pobyt ve stanovém táboře na poli (snad u Miloslavova) a na pro něj dosud neznámou stravu: špekáčky. ${ }^{70}$ Tato vágnost dochovaných svědectví však podle všeho nejde pouze na vrub věku narátorů nebo dočasnosti pobytu v zemi nikoho, ale také její neuchopitelnosti a nepojmenovatelnosti, alespoň za použití běžné terminologie popisující zkušenost uprchlíků a/nebo dějin holokaustu. Proto analýza země nikoho nemůže než začínat právě touto absencí a použitou terminologií.

Pro vzpomínky mnoha pamětníků je charakteristické, že přinejmenším improvizovaná země nikoho na demarkační linii nemá místní jméno - jako místo vyloučení, jež nikam nepatř́, jej přece ani mít neměla. Ani Egon Schwarz toto místo nepojmenovává - je to prostě prostor na jedné straně vymezený mad’arskými a na druhé straně československými ozbrojenci. ${ }^{71}$ Naprŕklad Grigory Beck, který se spolu s rodinou zřejmě ocitl v zemi nikoho u Velkého Kýru, vzpomínal na deportaci z Nitry směrem k Novým Zámkům takto: „,...nazývalo se to Niemandsland [pamětník používá německý termín v rozhovoru vedeném v ruštině, M. F.], měli jsme tam hlad, nebyla tam voda, nic. Vyvezli nás v pátek večer a nic neřekli - Hlinkova garda, ti fašisté." Z2 Zoltán Breiner z Humenného, deportovaný jako šestiletý, v době, kdy nastoupil do první tř́ídy, také nezmiňuje

68 Naopak příliš věrohodné není tvrzení Arona Grünhuta, podle nějž bratislavská ortodoxní obec v zemi nikoho u Miloslavova hned na počátku pomocné akce postavila dřevěné baráky. GRÜNHUT 1956, s. 26.

69 NA, f. HO 294, file 53 (Prague correspondence), Zpráva Beatrice Wellington, 17. prosince 1938.

70 USC Shoah Foundation Visual History Archive (USC SF VHA), Dave Lux, Interview Code:13251, 14. 3.1996.

71 SCHWARZ 2009, s. 69-72.

72 USC SF VHA, Grigory Beck, Interview Code: 35975, 23. 11. 1997. 
místo - „tak sme celá naša rodina a desiatky d’alších rodín ostali v hraničnom pásme asi 14 dní. Bývali sme v stohu slamy až do návratu do Humenného. ${ }^{173}$

Snáze než názvem byla země nikoho proto popsána cestou, kterou bylo třeba podstoupit. Schwarz např́ílad ve svých vzpomínkách vylíčil deportaci z Dunajské Stredy poté, co se ve městě etablovala mad’arská moc. Zvláštním vlakem byli posláni pod dohledem mad’arských četníků do neznáma - ve skutečnosti směrem na Bratislavu a byli vysazeni v některé ze zastávek před demarkační čarou. Venkovskou krajinou museli pak - v nejistotě a za pláče dětí - pokračovat pěšky. Noc strávili namačkáni $\mathrm{v}$ jakémsi zemědělském stavení a ráno museli bez snídaně pochodovat dále. Ještě předtím byli donuceni strážcům odevzdat cennosti a poslední úspory, a pak je eskortovali na rozbahněné pole mezi liniemi.

Beatrice Wellington se již před návštěvou dozvěděla německý název blízkého místa Mischdorf, ale v samotném popisu návštěvy jej nepoužívá. Před cestou navštívili českého vojenského velitele, který Wellington a jejímu kolegovi s novinářským průkazem vydal propustku a na vojenské mapě ukázal pozici „tábora“. „Z Bratislavy jsme se vydali autem zhruba ve dvě hodiny. Hlavní silnice touto oblastí byla v mad'arských rukou, a tak jsme museli jet polními cestami. $15 \mathrm{~km}$ nám trvalo téměr hodinu. [...] Najednou se na této rozsáhlé pláni zoraných polí a občasných stromů objevil spletenec ostnatých drátů a pár kouřících vyvýšenin. To byl ,tábor! Těžko by si bylo možné vybrat bezútěšnější a nehostinnější místo."

Improvizovaná země nikoho mezi demarkačními liniemi neměla tedy pevné jméno, ani jasné obrysy. Její geografické vymezení proto bylo proměnlivé a bylo často popisováno jako místo za konkrétní obcí nebo mezi přesně určitelnými geografickými prvky. Rozhodnutí, zda a jak pojmenovat, nebo nepojmenovat, vypovídá o vnímání země nikoho jako prostoru postrádajícího základní vlastnosti běžně spojované s fyzickým místem: jasné vymezení, funkce - a jméno. Absence obvyklých fyzických struktur (uliční sít', domy či základní infrastruktura) jistě přispěly k pocitu, že nešlo pouze o deportaci do jiného prostoru, ale také za hranice společnosti řádných občanů. Odmítnutím popsat jej jménem se tak země nikoho, přinejmenším ta improvizovaná na demarkační čáře, stává protikladem skutečného místa jako sociálního prostoru.

Pojem země nikoho je doložen přinejmenším od doby raného středověku jako ohraničený prostor a místo vyloučení. ${ }^{75}$ Součástí evropské kulturní tradice a všeobecně srozumitelným referenčním pojmem se však stala teprve jako součást reflexe první světové války. Zachycovala zkušenost vojáků ve válce nového typu a vztahovala se jak k fyzickému prostoru mezi liniemi zákopů, pro něž platila vlastní pravidla, tak i v přeneseném slova smyslu - k vytržení ze sociálních kontextů domova, školy či práce a nekompatibilitu válečné zkušenosti s tou civilní. Podle historika Erica J. Leeda je v kulturní reflexi první světové války země nikoho ztělesněním liminality válečné

73 VRZGULOVÁ, Monika. Deti Holokaustu. Bratislava : Dokumentačné stredisko holokaustu, 2007, s. 53.

74 NA, f. HO 294, file 53 (Prague correspondence), Zpráva Beatrice Wellington, 17. prosince 1938.

75 LESHEM, Noam - PINKERTON, Alasdair. Re-inhabiting no-man's land: genealogies, political life and critical agendas. In Transactions of the Institute of British Geographers, 2016, roč. 41, č. 1, s. 41-53. 
zkušenosti. Je to „pojem, který zachycoval esenci zkušenosti poslání za vnější hranice společenského života, umístění mezi známé a neznámé, povědomé a tajemné." ${ }^{16}$

Obraz země nikoho mezi frontami první světové války byl v roce 1938 překvapivě snadno, téměř jako samozřejmost, přenesen na situaci uprchlíků mezi hranicemi. Přispěla k tomu nejen podobnost situace lidí zadržovaných v nehostinném prostoru mezi fyzickými liniemi, ale také postavení marginalizovaných lidí ocitajících se mimo „civilizovanou“ společnost. Je ale pozoruhodné, že se tato metafora rozšíŕila v regionu, v němž za první světové války země nikoho nehrála zásadní roli. Zatímco ta byla charakteristická pro západní frontu s rozvětvenými zákopy a nehostinným prostorem mezi nimi, na východě od německých hranic - kde se v roce 1938 nacházela naprostá většina vojenských zemí nikoho - byly fronty podstatně dynamičtější.

Článek Mileny Jesenské, v němž očividně čerpá ze zprávy Marie Schmolkové, ilustruje tuto aktualizaci válečné země nikoho na podmínky židovských uprchlíků v roce 1938. „Před mnoha lety jsme viděli v Praze film, který se jmenoval »Země nikoho«," píše tato česká novinářka v Peroutkově Př́tomnosti v textu o uprchlících mezi hranicemi. „Od té doby jsme neviděli film tak krásný a obávám se, že uplyne mnoho vody, než budou lidé smět ř́kat a ukazovat pravdu takovým způsobem, jako to tehdy dovedli v Němec$k u .{ }^{\prime \prime 7}$ Jesenská odkazovala na německý film z roku 1931 natočený režisérem a scénáristou Victorem Trivasem. ${ }^{78} \mathrm{~V}$ něm svede osud dohromady pět vojáků $\mathrm{z}$ válčících armád v zákopu v zemi nikoho: Francouze, Angličana, Němce, černocha (sloužícího v britské armádě) a ruského Žida. Jak poznamenal filmový historik Jerzy Toeplitz, nejde o zřetelně vykreslené, individualizované postavy, ale o symboly. Každý z nich ve filmu hovoří vlastním jazykem a nese vlastní identitu, a přesto postupně nacházejí společnou řeč a odhalují nesmyslnost války. V závěrečné scéně společně vyjdou ze zákopu a překračují ostnatý drát. Neudiví proto, že po nástupu nacistů v roce 1933 padl tento protiválečný film za obět' cenzuře. ${ }^{79}$

Co se ve filmu, jehož děj se odehrával za první světové války, ještě před pár lety zdálo vzdálenou minulostí, je nyní podle Jesenské „za humny, co by kamenem dohodil“. Navíc zatímco ve filmu se země nikoho stává místem usmíření nepřátelských vojáků, zemi nikoho roku 1938 chyběla jakákoli optimistická perspektiva. Jesenská zdůrazňuje postavu ruského židovského vojáka, který v důsledku šoku z výbuchů ztratí řeč. Zajímal ji nejen její představitel, herec Wladimir Sokoloff, muž s „typickýma očima židů: tmavýma, smutnýma očima, hledícíma z věků do věkư". Postavu samotnou považovala za věšteckou: „[...] člověk němý mezi mluvícími, poznamenaný i mezi vyhoštěnými..." ${ }^{\text {"0 }}$ Touto kulturní reprezentací Jesenská vytváří narativní spojení mezi liminální zkušeností zákopové války a židovským osudem vyháněných lidí bez domova. Kdo

76 LEED, Eric J. No man's land. Combat \& identity in World War I. Cambridge; New York : Cambridge University Press, 1979, s. 15.

77 JESENSKÁ, Milena. V zemi nikoho. In Přítomnost, 1938, roč. 15, č. 52, s. 828-829; z tohoto článku cituje řada prací, namátkou NIŽŇANSKÝ 1999, s. 56.; WEIN, Martin Joachim. History of the Jews in the Bohemian Lands. Leiden; Boston : Brill, 2016, s. 180.

78 TRIVAS, Victor. Niemandsland / Hell on Earth. 1931. Dostupné na internetu: http://archive.org/details/ HellOnEarth.

79 TOEPLITZ, Jerzy. Geschichte des Films, sv. 2: 1928 - 1933. Berlin : Henschel, 1976, s. 219-220.

80 JESENSKÁ 1938. 
jiný než němý židovský voják měl reprezentovat vyloučené uprchlíky bez hlasu, beze jména a bez zastání.

\section{Zóna ilegality}

Země nikoho svými vlastnostmi negovala důvod, pro nějž vznikla: snahu o ochranu přesně definovaných hranic, jež měly oddělovat suverénní státy a znemožňovat ilegální přechod. Místo toho lidé v nejasně určeném prostoru mezi liniemi zpochybňovali suverénní moc národního státu a spoluvytvářeli rozsáhlé zóny ilegality charakteristické pašováním, černým obchodem a korupcí. Vzpomínky Arona Grünhuta, jež byly dosud interpretovány především z perspektivy pomoci a záchrany, ${ }^{81}$ představují cenný dokument přibližující rozšíření nelegálního jednání jako součásti humanitární práce, a to i přes nepřesnosti, pravděpodobné zveličování vlastních zásluh a jednostrannost ve vztahu k sionistickým a ostatním pomocným aktivitám. Grünhut a podobní však byli ideálními pomocnými pracovníky nejen pro organizační a materiální zázemí ortodoxní obce, ale také pro zkušenost, která se hodila pro pomoc v dynamické situaci bez pevných pravidel. Se znalostí regionu a jazyků, platnými doklady a schopností improvizace neváhal Grünhut apelovat a přesvědčovat, ale také podplácet a pašovat, aby pomohl souvěrcům v nouzi.

Například již v dubnu 1938 intervenoval u mad'arských úřadů ve prospěch skupiny 28 Židů vyhnaných z Frauenkirchenu v Burgenlandu, kteří byli zadrženi na mad'arské hranici poblíž Karlburgu (Rusovce), kde ve stáji, na slámě, očekávali své vrácení přes hranice. Líčil svou intervenci u místního velitele pohraniční stráže, na kterém přes jeho původní odmítavý postoj neústupností a slzami vymohl jednodenní odklad odsunutí uprchlíků zpět do Rakouska. Následně se mu podařilo v Budapešti získat povolení vedoucího organisace KEOKH (Centrálního úřadu pro kontrolu cizinců), Akose Amona Pasztoie, ${ }^{82}$ který souhlasil s ilegálním přesunem této skupiny na Slovensko. Za pomoci místních Židů byli pak v noci na povozech dopraveni k Dunaji u obce Rajka a v dobře připravené pašerácké akci na rybářských člunech přepraveni do Gutoru (Hamuliakovo). Českoslovenští pohraničníci byli očividně podplaceni a v určenou hodinu se stáhli. Ještě téže noci byli zachránění a osobními auty rozvezeni na různá místa na Slovensku. ${ }^{83}$

Podobným způsobem se snažil pomoci skupině zhruba 60 Židů z Kittsee a Pamy, kteří byli v polovině dubna 1938 v noci nacisty na člunech převezeni na ostrov pod Děvínem (Theben). Bratislavská ortodoxní obec si na policejním ředitelství vymohla, aby jim mohla poskytnout bezodkladnou pomoc - stravu a oblečení, nedokázala ale zabránit jejich vrácení přes hranici. Na krátkou dobu jim Grünhut zajistil provizorní ubytování na statku na rakouském území, kde se stýkaly hranice všech tří států; potom byli v zemi nikoho v Rajce. Brzy se však ukázalo, že ilegální převoz přes Dunaj již kvůli zostřeným bezpečnostním opatřením není možný, a tak vynalézavý Grünhut

81 MOZER, Martin (ed.) Aron Grünhut. Záchranca Židov a bojovník za l'udské práva. [s. l.]: Paradysio.

82 K činnosti organisace KEOKH viz FROJIMOVICS, Kinga. I have been a Stranger in a Strange Land. The Hungarian State and Jewish Refugees in Hungary, 1933 - 1945. Jerusalem : International Institute for Holocaust Research, Yad Vashem, 2007.

83 GRÜNHUT 1972, s. 9-12. 
musel hledat jiné řešení: $v$ tomto případě se ortodoxní obci podařilo zajistit vlečný člun francouzské plavební společnosti, který kotvil v bratislavském zimním přístavu a nyní byl přesunut na madarskou stranu Dunaje k Rajce. Na něm našli burgenlandští Židé na několik měsíců dočasné útočiště.

Tuto zkušenost a stejné schopnosti uplatňoval také při pomoci Židům na poli za Miloslavovem. Zprávu o nich bratislavské ortodoxní obci přinesl rolník, který si vypovězených povšiml, když jel obdělávat pole - byl mezi nimi také jeho známý. Grünhut organisoval spolu s dalšími členy židovské obce pomocnou akci: dodávali potraviny a další potřeby a do země nikoho přitáhli několik stěhovacích vozů. Podobně jako v předchozích pomocných akcích se nebáli ilegálního pašování lidí: V nákladních vozech, kterými přiváželi zásoby, pak aktivisté tajně převáželi některé z vyhnanců zpět na Slovensko, zatímco českoslovenští vojáci, zásobení cigaretami, nedbale kontrolovali. ${ }^{84}$ Tímto způsobem se zachránil i Egon Schwarz a jeho rodiče: jednoho dne v řidiči nákladního vozu se zásobami poznali jejich energického strýce z Bratislavy. Nenápadně vklouzli na korbu a skryti pod vyprázdněnými pytli dojeli do Bratislavy, kde se schovali u př́buzných. ${ }^{85}$

\section{Opuštění ve vnitrozemí}

V patové situaci mezi (česko)slovenskými a mad’arskými vládami převzaly zřejmě iniciativu místní úřady a styční důstojníci obou armád, kteří na konci listopadu nejméně dvakrát jednali ve Velkém Kýru. Slovenská strana se zavázala přestat s vypovídáním Židů, bez ohledu na státní př́íslušnost, a slovenská vláda nakonec povolila vpustit na slovenské území Židy, kteří se mohou prokázat tamější př́íslušností - ostatní, tj. Židy příslušné do Polska, Čech či Podkarpatské Rusi je možné odeslat pouze tam. ${ }^{86}$ Na základě výše zmíněného nařízení z 8. prosince 1938 pak byli převzati ostatní lidé ze země nikoho.

Nicméně to nemělo znamenat změnu jejich statutu: spíše se, podobně jako ve Zbąszyńi či v jihomoravských Ivančicích, jednalo o přesun země nikoho, ve smyslu vyloučení a odmítnutí zodpovědnosti státu, do vymezených prostorů ve vnitrozemí. Internační tábory vnímala slovenská vláda de facto jako enklávy vně legálního rámce národního státu: podle nařízení z 8. prosince neměli mít jejich nucení obyvatelé dokonce povinnost zařídit si povolení pobytu podle zákona o pobytu cizinců z roku 1935 - jako by ani nebyli na území Česko-Slovenska. Důsledkem bylo naprosté opuštění uprchlíků v zemi nikoho - té první, improvizované, stejně jako její pozdější organizované podoby. S opuštěním šla ruku v ruce závislost na židovské sociální péči. Ortodoxní židovská obec v dopise Tisovi, v němž na konci listopadu 1938 apelovala na převzetí uprchlíků na slovenské území, přislíbila „hradit’ všetky možné výlohy tak, aby s pripustením spomenutých osôb na územie Slovenska ani krajine ani jednotlivým obciam žiadne výdavky nevznikli. ${ }^{187}$ Internované se zavázala na

84 Tamže, s. 27.

85 SCHWARZ 2009, s. 72-73.

86 SNA, f. KÚ BA, k. 309, č. j. 74226/38 prez., Telefonické hlášení okresního náčelníka Náčina, 24. listopadu 1938. 87 SNA, f. KÚ BA, k. 309, č. j. 77581/38 prez., Žádost ústř̌ední kanceláře ortodoxních židovských obcí, 29. listopadu 1938. 
vlastní náklady ubytovat $\mathrm{v}$ oddělených budovách pod přísným policejním dozorem a postarat se též o stravu a léčení.

Uprchlíky z Velkého Kýru nejprve převzal okresní úřad v Nitře a umístil je $\mathrm{v}$ „koncentračním táboře " v židovské nemocnici v Nitře, kde byli dezinfikováni (a zřejmě také ve Zlatých Moravcích) - odtud byli následně přebíráni jednotlivými okresními úřady. ${ }^{88}$ Ze 158 lidí 50 převzaly jiné okresy: 17 Židů bylo například umístěno ve zvláštním domě v Topolčanech, osm v pieštanském židovském starobinci a tříčlenná rodina $\mathrm{v}$ židovském chudobinci v Bánovcích nad Bebravou. ${ }^{89}$ Přinejmenším tábory v Nitře a Topolčanech existovaly alespoň do začátku února $1939 .{ }^{90}$

Ne všichni byli ale internováni - pro to na mnoha místech nebyly vhodné prostory a okresní hejtmané to ani někdy nepovažovali za nezbytné. Do Diviacké Nové Vsi se tak - po dezinfekci v Nitře - mohla vrátit čtyřčlenná rodina s polským občanstvím. Dostali lhůtu do 1. března 1939 na uspořádání osobních záležitostí a „dobrovolné vystěhování ${ }^{11}$ Přinejmenším sedm deportovaných bylo uvolněno z tábora v Nitře a mohli se vrátit do Zlatých Moravců, když místní židovská obec přijala záruku za jejich vydržování. ${ }^{92} \mathrm{Z}$ těch, kteř́ nebyli převzati, okresní náčelník v Nitře 31 odeslal do domovských obcí na Podkarpatské Rusi a zbylých 77 , kteří většinou byli bez občanství nebo jejich př́islušnost byla sporná, internoval v židovské nemocnici v Nitře. ${ }^{93}$

Podobně probíhalo přebírání lidí u Miloslavova. Dne 9. prosince se např́íklad směla do Pezinku na tři měsíce vrátit šestičlenná rodina - tam měli do svého vystěhování žít pod policejním dohledem (podle všeho tam však zůstali až do deportací v roce 1942).$^{94}$ Dne 19. prosince československé úřady z Miloslavova převzaly 118 „židovských příslušníkủ", mezi nimi 36 dětí. Byli umístěni v improvizovaném táboře v Kühmeyerově hostinci u Červeného mostu (Rote Brücke) na okraji Bratislavy a pečovala o ně bratislavská ortodoxní obec. ${ }^{95}$ Podle vzpomínek Arona Grünhuta však němečtí majitelé hostince dali židovské obci po krátké době výpověd' a tábor byl přesunut do prázdných objektů blízké Patrónky, bývalé muniční továrny. ${ }^{96}$

V improvizované ubytovně na Červeném mostě panovaly velmi stísněné podmínky. Prostor byl rozdělen dřevěnými přepážkami a byl vytápěný, ale nedal se snadno odvětrávat. Kvůli nedostatku místa nebylo možné oddělit nemocné do zvláštní místnosti. Uprchlíkům byl povolován pouze občasný pobyt na dvoře, většinu doby ale museli trávit uvnitř - z toho měla vycházet narůstající podrážděnost a hádky kvůli maličkostem.

88 SNA, f. KÚ BA, k. 309, č. j. 2994/39 prez., Hlášení okresního náčelníka v Hlohovci, 30. ledna 1939.

89 SNA, f. KÚ BA, k. 309, Hlášení okresních náčelníků v Topolčanech, 13. února 1939, v Piešt́anech, 22. prosince 1938, v Bánovcích nad Bebravou, 31. ledna 1939.

90 JDC Archives, f. New York Office 1933 - 44, file 541, Report on the refugee camp in Bratislava - Rote Bruecke, 8. února 1939 (překlad).

91 SNA, f. KÚ BA, k. 309, Hlášení okresního náčelníka v Prievidzi, 2. února 1939.

92 FIAMOVÁ 2011a, s. 230.

93 SNA, f. KÚ BA, k. 309, č. j. 77581/38 prez., Hlášení okresního náčelníka v Nitře, 21. února 1939.

94 SNA, f. KÚ BA, k. 309, č. j. 77581/38 prez., Hlášení okresního náčelníka v Modre, 7. února 1939; Databáze obětí Yad Vashem, Dostupné na internetu: https://yvng.yadvashem.org/nameDetails.html?itemId=1065242.

95 SNA, f. KÚ BA, k. 309, č. j. 77581/38 prez., Hlášení policejního ředitele v Bratislavě, 31. ledna 1939.

96 GRÜNHUT 1972, s. 30-31. 
O stupňující se nejistotě a pocitu vyloučení vypovídá též stížnost uprchlíků, v níž požadují, aby byli lépe informováni o jednáních o emigraci v Paříži a v Londýně. ${ }^{97}$

Tábor u Červeného mostu a následně na Patrónce umožňuje zařadit zkušenost země nikoho do širších souvislostí. Především vyloučení Židů do zvláštního prostoru úzce souviselo s nuceným vystěhovalectvím: židovské organizace při likvidaci země nikoho slibovaly rychlé vystěhování uprchlíků. Podobně jako v případě skupiny burgenlandských Židů, kteří po měsíce přežívali na nákladním člunu zakotveném na Dunaji, prioritizoval HICEM a další organizace emigraci lidí ze země nikoho na slovensko-mad’arském pomezí. Týkalo se to též těch, kteří odtud ilegálně utekli:

Egonu Schwarzovi a jeho rodičům paradoxně pobyt v zemi nikoho pomohl k další emigraci a pravděpodobně zachránil život. Za pomoci židovské vystěhovalecké organizace HICEM v Praze a Pařiži se mohli na jaře 1939 ve Francii nalodit na lod' do Jižní Ameriky, vybaveni vízy do Bolívie. ${ }^{98}$

Souvislost s vystěhovalectvím nebyla pouze organizační, ale také prostorová - vytvářením de facto extrateritoriálních emigračních či transmigračních zařízení či táborů. Také v Červeném mostu byla emigrace klíčovým tématem: pomocné organizace zde vybíraly vhodné kandidáty pro cestu do Velké Británie či děti, které mohly být zařazeny do dětských transportů. Isidor Pinkasovič uvedl, že ze země nikoho byli odvezeni do internačního baráku v Červeném mostě: pamatoval si - pro dítě z Podkarpatské Rusi - obrovskou budovu, v níž je měla hlídat Hlinkova garda. Přes běžný zákaz vycházení směly děti v doprovodu vychovatelů občas na výlety. Jeho jednou z posledních vzpomínek na rodiče byl svátek Purim strávený v táboře, při němž se tatínek převlékl do masky. Pamatoval si dvě návštěvy mladé anglicky hovořící sociální pracovnice, jež nakonec rodiče přesvědčila, aby jej i s o rok starším bratrem poslali dětským transportem do Anglie. ${ }^{99} \mathrm{Z}$ Červeného mostu byli odvezeni do Prahy - údajně v den okupace českých zemí, 15 . března $1939 .{ }^{100}$

Kontinuita tábora u Červeného mostu a později na Patrónce, v němž bylo možné shromažd'ovat další cizí Židy i ty bez státní příslušnosti, zatím nebyla předmětem detailnějšího výzkumu. Např́íklad podle zprávy z února 1939 na Červený most přibyl další uprchlík bez státní příslušnosti, který byl několikrát poslán přes slovensko-mad’arskou hranici a přes polskou hranici a který strávil měsíc ve vězení kvůli ilegálnímu návratu do Bratislavy. Teprve na základě intervence byl přesunut do uprchlického tábora. ${ }^{101}$ Patrónka se také brzy stala průchozím táborem pro transporty středoevropských Židů do Palestiny, ${ }^{102}$ s nimiž také přinejmenším někteří z uprchlíků ze země nikoho odcestovali. V roce 1942 byla pak Patrónka znovuotevřena jako shromaždiště před deportacemi židovských žen do Osvětimi. ${ }^{103}$

97 JDC Archives, f. New York Office 1933 - 44, file 541, Report on the refugee camp in Bratislava - Rote Bruecke, 8. února 1939 (překlad) and letter from the refugee camp in Bratislava to Dr. Platchik.

98 SCHWARZ 2009, s. 74-83.

99 Je možné, že šlo o Beatrice Wellington - také její návštěva v zemi nikoho u Miloslavova jen den před jejím uzavřením mohla souviset s pomocí s vystěhováním.

100 USC SF VHA, Interview Code:13251, Dave Lux, 14. 3. 1996.

101 JDC Archives, f. New York Office 1933 - 44, file 541, Report on the refugee camp in Bratislava - Rote Bruecke, 8. 2. 1939 (překlad).

102 Viz např. USC SF VHA, Interview Code: 24364, Liselotte Steckl, 18. 12. 1996.

103 FIAMOVÁ, Martina. Koncentračné stredisko Bratislava - Patrónka. In MEDVECKÝ, Matej (ed.) Fenomén 


\section{Až do odvolání...}

„Horká voda, mýdlo, postel! Od této noci vím, co je to luxus," reflektoval Schwarz svůj ilegální návrat do „civilizace“. Ale jeho dalším životem a dlouhým putováním Jižní Amerikou, a nakonec Spojenými státy ho doprovázelo ještě další poznání nabyté v zemi nikoho, „Že každá př́slušnost, každé právo, každé společenství spočívá na iluzi, zapůjčeny až do odvolání těmi u moci, mohou být odebrány podle jejich rozmaru. ${ }^{104}$

Význam vyloučení z občanství, zakoušený a vizualizovaný v improvizovaných tábořištích mezi liniemi, přesahuje jejich omezený prostorový a časový rámec. Zkoumání země nikoho roku 1938 tak vede ke kritickému pohledu na národní stát. Političtí filozofové Hannah Arendt a Georgio Agamben ve svých pracích reflektovali vylučování uprchlíků moderními národními státy a jejich zbavování práv (či samotného práva mít práva). Arendt se zaměřila na situaci lidí bez státního občanství a vytváření „bezdomovectví", zatímco Agamben teoretizoval fenomén zvláštního stavu jako státem vytvořeného prostoru, $v$ němž se právo míchá s bezprávím a v němž jsou vylučovaní redukováni na pouhý, biologický, život. ${ }^{105}$ Ovšem jestliže oba vlivné př́ístupy jsou vynikajícím nástrojem pro kritiku vylučujících tendencí národních států, nepočítají zároveň se situací absence státu nebo př́mého fyzického násilí. Ačkoli Agambenův výjimečný stav může být užitečnou metaforou pro proces vyloučení, který vedl k izolaci v zemi nikoho, podobně jako dokumenty státu končí na jeho „hranici“. Pro výzkum holokaustu, stejně jako uprchlíkủ, je zkušenost země nikoho roku 1938 cenná tím, že přitahuje pozornost $\mathrm{k}$ situacím, v nichž jsou stát nebo další dominantní či násilní aktéři nepř́tomní, a umožňuje promýšlet limity národního státu a na něj navázaných interpretací a př́stupů.

I když byla země nikoho zdánlivě zlikvidována již po několika týdnech, v prosinci 1938, ve skutečnosti byl prostor vyloučení a vzdání se zodpovědnosti státu pouze přesunut z demarkační linie do vnitrozemí. V Nitře, Červeném mostu, na Patrónce a na dalších místech, nebo například $v$ jihomoravských Ivančicích, přetrvávaly prostory, $v$ nichž byli izolováni lidé, za něž stát odmítal přijmout zodpovědnost a k nimž přistupoval, jako by nebyli na jeho území. Jestliže James Ward upozorňuje na zásadní vliv první Vídeňské arbitráže a slovenských obav o udržení národního území na další průběh pronásledování a genocidy Židů, stejně tak je důležité sledovat delší život země nikoho, její nejasné hranice, kontinuitu a rozšiřování do vnitrozemí.

Větší frekvence, zvyšující se počty postižených a delší trvání země nikoho na hranicích středovýchodní Evropy roku 1938 souviselo s několika faktory: radikalizací pronásledování a vyhánění Židů v nacistickém Německu a uzavírání hranic pro uprchlíky, zejména těch židovských. Teritoriální revize ve prospěch nacistického Německa a později Mad’arska a Polska uvedly do pohybu základy národních států vytvořených v roce 1918 a znejistily jejich hranice, občanství i politické systémy. Země nikoho

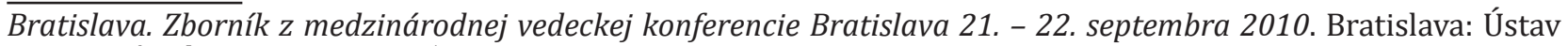
pamäti národa, 2011, s. 230-250.

104 SCHWARZ 2009, s. 73.

105 ARENDTOVÁ, Hannah. Původ totalitarismu. Praha : OIKOYMENH, 1996; AGAMBEN, Giorgio. Homo sacer. Suverénní moc a pouhý život. Praha : OIKOYMENH, 2011. 
doprovázela rozsáhlé revize občanství, v jejichž rámci v Rumunsku, Polsku, Československu i dalších zemích byli Židé považovaní za cizí a zbavováni státní příslušnosti. Ačkoli bylo československé vládní nařízení o přezkumu občanství z ledna 1939 zaměřeno zejména proti židovským uprchlíkům z českého pohraničí, uplatňovala slovenská autonomní vláda podobný př́stup $\mathrm{k}$ Židům s domovským právem v odtrženém pohraničí a těm, kteří se na Slovensko přistěhovali. Významná část deportovaných navíc podléhala revizi občanství polských Židů žijících v zahraničí.

$\mathrm{V}$ přeneseném slova smyslu se země nikoho stala symbolem masového zbavováním Židů ve středovýchodní Evropě formálního občanství a občanských práv. Přístup, který byl v roce 1938 testován na židovských vyhnancích a uprchlících, byl například jen o něco později uplatněn na všechny slovenské Židy, bez ohledu na formální občanství. Země nikoho tak ukazuje na význam uprchlíků v transnacionálních procesech eroze občanství Židů a na to, že přechod k chápání židovských občanů jako uprchlíků či nepř́íslušejících "východních Židů“ nebyl pouze výsledkem tlaku a vlivu nacistického Německa, ale vstupovaly do něj také lokální aspekty a iniciativy. Jak ilustrují slovenské deportace z listopadu 1938 a země nikoho na československo-mad’arské demarkační čáře, hrála v něm významnou roli také vzájemná interakce národních států ve středovýchodní Evropě, jež skrze vylučování uprchlíků a na svých hranicích komunikovaly měnící se představy o židovském občanství v tomto multietnickém regionu.

Cituj:

FRANKL, Michal. Země nikoho 1938. Deportace za hranice občanství. In Forum Historiae, 2019, roč. 13, č. 1, s. 92-115. ISSN 1337-6861. DOI: https://doi.org/10.31577/forhist.2019.13.1.7

-..

Mgr. Michal Frankl, Ph.D.

Masarykův ústav a Archiv AV ČR, v. v. i.

Gabčíkova 2362/10

Praha 8

18200

Česká republika

frankl@mua.cas.cz 